(c) The Author(s), 2021. Published by Cambridge University Press. This is an Open Access article, distributed under the terms of the Creative Commons Attribution licence (http://creativecommons.org/licenses/by/4.0/), which permits unrestricted re-use, distribution, and reproduction in any medium, provided the original work is properly cited. doi:10.1017/S1474746421000026

\title{
Deserving of Social Support? Street-Level Bureaucrats' Decisions on EU Migrants' Benefit Claims in Germany
}

\author{
Nora Ratzmann
}

Centre for Analysis of Social Exclusion, London School of Economics and Political Science, UK E-mail: n.ratzmann@/se.ac.uk

Migration raises the question of how street-level bureaucrats treat non-citizens when it comes to the distribution of limited welfare resources. Based on a German case study, this article reveals how local social administrators rationalise practices of inclusion in and exclusion from social assistance receipt and associated labour market integration services for mobile EU citizens, who are perceived first and foremost as 'foreigners'. The findings from fifty-five qualitative interviews with job centre representatives show how politics of exclusion are justified by nationalistic and ethnic criteria of membership. Insofar as EU migrants are considered outsiders to the imagined welfare community of their host country, they are seen as less deserving than German-born claimants. However, mobile EU citizens can earn their legitimacy to access benefit receipt through sustained participation in the host society, demonstrating knowledge of the German language and societal norms so as to appear 'German'. Such a cultural performance-based logic of deservingness tends to be intertwined with nationality-based and racialising stereotypes of welfare fraud to frame exclusionary practice.

Keywords: EU social citizenship, policy implementation, street-level bureaucracy, deservingness, belonging.

\section{Introduction}

In the European context, membership claims to a community of solidarity, which underpin access to public welfare resources and services, have traditionally been delineated nationally (Soysal, 1994). Immigration fundamentally challenges this territorially bound conception of welfare entitlements, as not every resident living in a predefined national territory is a national citizen. Such changing demographics raise the question of who belongs to a community of solidarity and what rationale provides the basis on which social distribution ought to take place.

In this context, mobile EU migrant citizens' access to welfare benefits and services offers a compelling case study. While much public and scholarly attention has focussed on immigrants from the Middle East, intra-EU migrants who have come from another EU member state to live in Germany, also called mobile EU citizens, now constitute one of the largest immigrant groups in Germany (Bundesamt für Migration und Flüchtlinge, 2018). In law and policy, intra-EU migrants form a particular group of immigrants, enjoying a privileged legal status compared to third-country nationals. Mobile EU citizens can move to (and reside mostly without restrictions in) another EU country, work there without a work permit or visa, and enjoy non-discriminatory treatment along with nationals in 
accessing employment and social advantages (Articles 18 and 21, Treaty on the Functioning of the European Union, and associated case law).

EU citizenship appears to imply formal equality of status between national citizens and mobile EU citizens resident in a member state other than their own. Yet scholarship demonstrates the stratified systems of entitlement created through national immigration and welfare regimes, which limit EU migrant citizens' access to social security benefits in their respective host countries (Shutes and Walker, 2017). What has remained less examined is how processes of implementation shape substantive access to benefits and services for non-nationals, a category of which mobile EU citizens are a case. As Maynard-Moody and Musheno (2012: 22) highlighted, 'questions of migration have moved to the fore', which raises interest in 'how street-level workers [...] respond to 'noncitizens' [...] [as] labelling people as noncitizens may alter judgements about social equity'. The associated body of literature on street-level bureaucracy has shown how administrators are far more than mere technocratic implementers of law and policy (Lipsky, 2010). Instead, they can shape substantive access to benefits and services as de-facto policy-makers, based on their perceptions of a claimant's apparent deservingness to state support or lack thereof (Dubois, 1996; Zacka, 2017). Street-level bureaucrats 'make moral judgements about the relative worthiness of the citizen client, and then they use rules, laws, and procedures to help those they consider worthy and punish those they deem unworthy' (Maynard-Moody and Musheno, 2000: 351).

Against this backdrop, the article explores how understandings of national belonging and deservingness are articulated by street-level bureaucrats involved in the implementation of social entitlements when it comes to non-national claimants. To do so, the research analyses ideas about 'us' and 'them', which serve street-level bureaucrats as lenses through which to reduce complex social circumstances into tangible categories for processing claims rapidly (see Bacchi, 2009). Such moral value frames set out assumptions on mobile EU citizens' apparent deservingness to claim benefits and appropriate solutions of inclusion in or exclusion from benefit receipt in practice. The findings reveal how local social administrators perceive the worthiness of mobile EU citizens to receive welfare benefits and associated labour market integration services, and how their views and decisions might impact the rationing of such publicly financed goods.

Drawing on semi-structured interviews with fifty-five job centre staff in Germany, the article's original qualitative analysis unravels an implicit, cultural performancebased logic which street-level bureaucrats in German job centres commonly apply when assessing claims of mobile EU citizens. The findings illustrate that policy implementation can lead to exclusionary practice, preventing some intra-EU migrant claimants from accessing social assistance benefits, despite demonstrable need and legal entitlements, due to extra-legal considerations of 'cultural performance'. Such identity-based ideas of deservingness find expression in expectations of EU migrant claimants to demonstrate national belonging to substantiate their social entitlements, in the form of German language skills and acquiescence to dominant societal and bureaucratic norms. What this finding implies is that ethnicity, defined as the belief in a common origin and shared cultural practices, may significantly shape ideas about national belonging and deservingness to access social benefits and services in Germany. 


\section{Mobile EU citizens' entitlements to German social security}

To elaborate on how street-level bureaucrats' ideas about deservingness of foreign national citizens to claim nationally-bound social security can play into local policy implementation, this section gives a brief overview of the policy context of labour market activation and migrant integration policies, including mobile EU citizens' legal entitlements in Germany.

In summary, the Hartz reforms of 2003-2005 shifted German social security from a rights-based system to one centred on deservingness, whereby claimants of insurancetype benefits are generally seen as more deserving than those receiving tax-financed social support (Heuer and Mau, 2015). The contemporary German social security system is divided into a statutory, contribution-based unemployment benefit (UB) I for those with sufficient insurance records, and a means-tested, tax-financed unemployment benefit $(U B)$ /l for jobseekers without sufficient prior financial contributions to German social security. In January 2020, the tax-financed, minimum UB I/ benefit for a single person, meant to ensure the constitutional requirement of a life of human dignity, amounted to 432 Euros per month. During individual case assessments, job centres determine whether individuals meet the conditions for benefit payments and sufficiently fulfil labour market activation requirements, such as active job searching and training (Zimmermann and Rice, 2016).

Mobile EU citizens from other member states who are exercising rights of free movement are entitled to some social benefits in Germany under the Freedom of Movement Law (FreizuegG/EU), which translated the relevant European directives into German national law. During the initial three-month period, no incoming EU citizen can claim any German social security benefit. Economically active mobile EU citizens can receive German subsistence benefits as income supplements to reach the social minimum if they become involuntarily unemployed or their income falls below that threshold. If EU claimants have worked and contributed to German social security for less than a year, jobseekers are entitled to the state's minimum welfare payments for a six-month period. After having worked for more than a year, German subsistence benefit can be received as long as needed. Economically inactive mobile EU citizens, however, can only receive non-contributory benefits once they reach so-called 'habitual residence' status, which corresponds to a five-year threshold of settling and living in Germany (Bundesgesetzblatt Nr. 65, Bundesregierung 12/28/2016).

Both the EU Free Movement Directive (EU Directive 2004/38/EC, Article 7) and corresponding German legislation on mobile EU citizens' social entitlements incorporate the principle of self-sufficiency. Job-seeking EU citizens' right to reside can be withdrawn if they are formally ruled an unreasonable burden on the host state's social system, effectively limiting to EU citizen-workers the right to freedom of movement and the right to claim social benefits in a host EU member state. This public policy trope of the self-reliant migrant worker contributing to the host society has become a marker of civic integration policies across European countries (Anderson, 2015). Following a logic of economic usability, only migrants who are not dependant, and hence no burden to the national welfare state, are deemed deserving (see Bonjour and Duyvendak, 2018 for the Dutch case). Breidahl (2012: 119) argued in the Scandinavian context that welfare activation programmes tend to operate based on welfare chauvinistic logics, whereby 'harsher policies have been introduced and implemented more eagerly when the target group for 
activation reforms has been immigrants'. Similarly, Dwyer et al. (2019) demonstrated in the UK context how the hostile environment to EU migrant claims is constructed via government policy.

\section{Moral judgements on claimants' deservingness in street-level implementation work}

As it is during the local implementation process that practitioners apply and interpret the abstractly written law to grant or refuse access to welfare benefits and services in practice, this section summarises some of the key tenets from street-level bureaucracy and welfare attitudinal research. In short, street-level bureaucrats, such as local job centre administrators, 'directly deliver policy to people' (Brodkin, 2013: 18). While processing claims, bureaucrats reduce people's unique life experiences and circumstances to a small range of standardised categories due to time constraints and limited information (Zacka, 2017). Bureaucratic procedural discretion allows for such pragmatic decisions. It can be exercised at several stages of the job-seeker's basic allowance claim, including decisions about documentation required for processing a claim or the application of sanctions once the benefit has been granted. As some literature demonstrates, street-level bureaucrats exercise such discretion by closely following rules or bending them based on the claimants' apparent deservingness to state support or lack thereof (Maynard-Moody and Musheno, 2000).

Empirical research on the role played by moral judgements in gatekeeping of social security provision includes German (Jewell, 2007), French (Dubois, 1996) and British studies (Wright, 2003). One dimension insufficiently explored in such studies is the interplay between moral judgements on a claimant's deservingness and ideas of national belonging, and their role in shaping administrative practices on the ground in relation to migrants' claims to social security. However, following assumptions laid out by welfare chauvinism research, which investigates public attitudes on immigrants' deservingness to access state-financed welfare support, mobile EU citizens are likely not to be regarded as belonging to the bounded community of solidarity in the same ways as their fellow German insiders. Negative views in public discourses portray immigrants as undermining the fiscal viability of national welfare states, a view related to economic concerns over immigrants triggering increased welfare dependency (Reeskens and van der Meer, 2015). Migration-related diversity is also understood to undermine the legitimacy of collective nationality-bound welfare arrangements, which have traditionally been intended for national citizens (van Oorschot, 2008).

While welfare administrators commonly discriminate between worthy claimants to include and unworthy claimants to exclude, further exploration is needed of how streetlevel bureaucrats perceive cultural and ethnic differences between claimant groups and how such ideas may impact in practice their decisions to exclude non-citizens, such as mobile EU citizens, from welfare benefit receipt. Considering intra-EU migrants' position as outsiders to the imagined welfare community of their host country, they are likely to come up against street-level bureaucrats' tendency to exclude them from benefit receipt. To better grasp what sorts of ideas about deservingness street-level bureaucrats may mobilise when assessing claims of mobile EU citizens, van Oorschot's (2006) framework on welfare attitudes, developed from public attitude data, is a useful heuristic. He proposed five criteria on which individuals tend to judge a claimant's social legitimacy 
in determining entitlement to benefit receipt: namely, being in control over one's situation, the respective level of need, reciprocity-informed ideas on previous or future contributions to society, behavioural compliance, and the role of a shared identity.

Identity within this study is approached through the lens of national belonging, which touches upon broader, more diffuse notions of multi-layered status ascriptions than legally granted membership by citizenship (Lockwood, 1996). As the analysis unpacks them, ideas about 'identity' encompass several intertwined processes. First, belonging or being 'foreign' to the German nation is based on ethnic conceptions of seemingly irreducible differences, which can be related to German citizenship policy historically being construed on the principle of descent (ius sanguinis) rather than civic elements. The 'other' becomes constructed based on observed behaviour, like an inability to communicate in German or to grasp cultural cues. Such thinking turns foreigners into 'ethnic outsiders' who do not belong, independently of their legal citizenship status. Ethnic understandings of belonging may subsequently produce processes of racialisation, whereby entire national groups are judged against pre-existing stereotypes. Stereotypical representations are particularly applied to Sinti and Roma groups, who may be portrayed as 'taking advantage of the system', and thus as 'morally inferior'. Simultaneously, welfare chauvinistic ideas of intra-EU citizens as migrants who 'have too many rights in the first place' are invoked, marking them less deserving of social entitlements than their Germanborn counterparts. However, the interview data also point to culturalist ideas, whereby foreigners may earn their deservingness to receive German social assistance-type benefits through cultural integration efforts.

\section{Methodological note on the qualitative research design}

Considering the focus of this research on street-level implementation dynamics, qualitative methods are an appropriate means of capturing the lived realities of everyday claiming and claims-processing. Provision of subsistence-type benefits in job centres constitutes a typical case of street-level work, as job centres supply claimants with essential services which cannot be obtained elsewhere. UB // benefits are the only social subsistence-type, means-tested income support available in Germany for those able to work. That country constitutes an interesting case because of its traditionally strong and developed welfare state, at the same time having been one of the leading countries to support recently incoming refugees and host many migrant EU citizens on its territory.

The findings build on fifty-five in-depth interviews (of thirty to ninety minutes' length) with job centre staff, carried out between June 2015 to July 2016, to explore the interplay between moral judgements on a claimant's deservingness and ideas of national belonging - that is, of being viewed as 'German' - which street-level bureaucrats may mobilise to exclude certain groups of mobile EU citizens from accessing subsistence benefits in Germany. To comprehensively cover the perspectives of different types of front-line staff, job centre representatives on different levels of the hierarchy (from the local job centre director to assistant administrators), and within the main organisational units (i.e. labour market, benefit and entrance zone teams) were interviewed. Variance in terms of gender, years of work experience, educational level and country of origin was taken into account whenever possible. The aim was to allow for the maximum variety of perspectives and voices (see Ratzmann, 2019: 85-88 for details). The study examined the implementation processes in a select number of cases in Berlin, choosing depth over breadth. Within 
Germany, Berlin, as the biggest agglomeration with its 3.6 million inhabitants, represents Germany's main migration hub, hosting three times more foreign nationals on its territory than the German average. About 38 per cent of the foreign resident population are EU migrants, mostly Bulgarian, Romanian, Italian and Polish nationals (Statistisches Bundesamt, 2017).

All interviews were transcribed in German to avoid mistranslation, and only translated into English during the analysis and writing processes. The findings emerged from two main methods of qualitative data analysis: namely, a more traditional close and interpretative reading of the interview scripts, and a relatively rigorous coding exercise (Tesch, 1990) based on a hybrid thematic analysis approach. Transcripts were coded after each round of fieldwork through the software NVivo, using emergent themes from the data (Miles and Huberman, 1994), along with categories developed from the topic guide. The findings on how ideas of national belonging may shape situational judgements of an EU claimant's deservingness and frame politics of exclusion emerged inductively and iteratively from the qualitative interview data analysis.

\section{Job centre administrators' views on EU migrants' deservingness to claim social assistance}

As briefly pointed to above, moral considerations of deservingness based on financial reciprocity, demonstrable need and behavioural conditionalities are embedded in the institutional architecture of the hybrid German social security system. To receive UB II subsistence-type benefits, claimants must have exhausted welfare entitlements from the social insurance system, must have undergone a means-test and must comply with job activation requirements. Hence, such principles were present in the interview data, as street-level bureaucrats relied on these rationales to justify mobile EU citizens' inclusion in or exclusion from substantive benefit receipt. Interestingly however, mobile EU citizens, commonly perceived as outsiders, had to earn their deservingness through an additional conditionality, in the form of demonstrating belonging through cultural knowledge, which Chauvin et al. (2013) summarised under the heading of performance-based deservingness. In the German context, this culturally infused logic tended to be tied to ethnic undercurrents. Mobile EU citizen claimants were expected to behave like, or to appear 'German' during the street-level interactions so that the local administrator in charge of their case would consider them deserving of German welfare state support.

In more detail, street-level bureaucrats primarily perceived mobile EU citizens as foreigners (EU Ausländer), despite the rhetoric of the European Commission which commonly portrays them as co-nationals with rights equal to those of national citizens of a member state. The use of language, through calling them EU foreigners rather than EU citizens, reveals how street-level bureaucrats implicitly categorised intra-EU migrants as outsiders to German society and the German community of welfare. Front-line bureaucrats tended to tie ideas of membership to nationalistic or ethnicising notions, distinguishing between what they discursively framed as 'native, real Germans', and 'others', which included both foreigners by citizenship and German national citizens of immigrant origin (see Ratzmann, 2019: 61-63).

Several of these street-level bureaucrats viewed mobile EU citizens as undeserving of German welfare support due to their non-German descent, as this interview excerpt exemplifies: 
Foreigners should not have access; the whole system does not function.

In these cases, mobile EU citizens' status as foreigners, marking ethnic descent, set the perceived boundaries of inclusion in and exclusion from welfare receipt. Such job centre respondents considered mobile EU citizens to be undeserving of German state support in principle because of their status as foreigners, despite their legal entitlements:

We have freedom of movement, which means that they [i.e. mobile EU citizens] can come here without any difficulties, $[\ldots]$ and we have many of them, and the law foresees $[\ldots]$ that they can top up their income through benefits.

The latter quote unveils how some street-level bureaucrats' ideas of deservingness could diverge from legally granted social entitlements. Even though the legal frameworks foresee that intra-EU migrant applicants in employment, whose income falls below the poverty threshold, can apply for $U B / /$ benefits as an in-work top-up, the above cited respondent viewed mobile EU citizens as undeserving, independent of their individual economic circumstances and employment situation.

With it came a professional role image as guardian of limited welfare state resources. Several job centre respondents considered the legislative framework insufficient to protect the taxpayer from what they regarded as an illegitimate financial burden and perceived it as their role to do so, as this local management interviewee explained:

We are stakeholders [sharing a common interest]. Stakeholders [or lobbyists] of the job centre, representing the interests of the taxpayer and the job centre.

In that context, part of the interviewed job centre staff portrayed mobile EU citizens as an endemic fiscal burden on the welfare state, thus displaying welfare chauvinistic attitudes to migrants as having 'too many rights in the first place'. To justify their view of excluding EU migrant claimants from benefit receipt, they commonly relied on the related trope of social tourism, as these quotes show:

There were [...] Greek, Spanish, Italians, young people, mid-twenties, around thirty, EU citizens, French. They directly came from the airport to the benefit office to live off 'Hartz IV' benefits in Berlin [...] it is irritating, because these are German taxes.

It is attractive for other Europeans to come here $[\ldots]$ but it is often abused.

Front-line staff questioning mobile EU citizens' legitimacy to social entitlements in Germany foregrounded ideas about intentional welfare fraud, which they often attributed to certain nationalities. This included portraying such behaviour as a seemingly natural characteristic, racialising the nationalities concerned:

A problematic group for us are EU citizens, mainly Romanians, Bulgarians, Polish. The danger is that they came for economic reasons, to receive social benefits here.

Our Eastern European immigrants, Romanians, Bulgarians, are known for that [i.e. fictitious selfemployment]. [...] and if they have been there for a year, self-employed, they can come here and apply for 'Hartz IV'. [ . . . I It's crazy what happens sometimes. But there are loopholes in the law which allow for that. 
Such extrapolating from individual occurrences of misconduct to intentional abuse by an entire national group qualifies as a form of cultural racism or ethnicism (Miles and Brown, 2003). Additionally, the nationalistic stereotypes that street-level bureaucrats sometimes mobilised often blurred nationality and ethnic descent in their line of reasoning, relying on anti-Roma prejudice to justify the exclusion of some Eastern European groups of mobile EU citizens:

It is the behaviour, and not ethnic belonging, which is the problem. Among Sinti and Roma there is a lot of fraud [...] Almost all receive social benefits.

What the above quotes illustrate is how some street-level bureaucrats relied on justifications of 'attitude' to frame undeservingness. They foregrounded misconduct to justify their discriminatory view of some national and ethnic groups, whom they considered to be all defrauding the system, by virtue of being members of the same group. In their framing, we can observe the blending of assumed behavioural traits with racialising views on Eastern European claimants, stereotyping them as welfare tourists.

Discursively framing some groups of intra-EU migrant claimants as undeserving of social benefit receipt, front-line staff expected them to be self-sufficient, mirroring the general policy discourse insinuated earlier. They commonly portrayed mobile EU citizens as economic migrants whose immigration to Germany was planned, and thus preparable in advance, which made them less deserving of state social support, as this labour market advisor explained:

Citizens who come from abroad and who never paid into the system [...] I would bar them from access if they are not asylum-seekers or refugees, but economic migrants and immigrants. $[\ldots]$ in my view it is not financially sustainable in the long run that most immigrated foreign claimants are unable and unwilling $[\ldots]$ to find a job and to integrate.

The latter quote illustrates how ideas about control over one's economic and employment situation upon arrival in Germany impacted street-level bureaucrats' perceptions of deservingness.

The excerpt also sheds light on an interlinked dynamic in the street-level politics of exclusion from social benefit receipt. Instead of considering mobile EU citizens undeserving of state welfare support due to their status as foreigners, some street-level bureaucrats framed their discretionary decisions as being conditional upon EU claimants' attitudes towards cultural assimilation. Such job centre respondents expected EU migrant claimants to demonstrate some knowledge of the German language and of tacit societal norms:

Problematic are foreigners who don't speak German [... they are too lazy to understand the official letters.

Here [in Germany], certain rules apply, and people normally have been socialised in a certain way. And I expect from my [foreign] clients that they assimilate, and it's not happening.

What the interview data revealed is that many job centre respondents expected migrants to first earn deservingness through active participation in the German host 
society, expressed by their willingness to integrate. Such linkage of acculturation efforts to the legitimacy of mobile EU citizens' receipt of tax-financed social benefits speaks to the 'culturalisation' of these citizens' social entitlements (see Mourão Permoser, 2017). Job centre staff tended to draw demarcations between 'us' and 'them' within the imagined community of welfare based on language, with attitude or willingness to learn the defining trait. Those mobile EU citizens who were unable to converse in German were framed as not belonging, and thus undeserving of public social support, as exemplified by the remark of this labour market advisor:

Often, they don't speak the language, but they tend to know how to get access. I find that bit annoying.

Acquiescence with the German language, commonly a marker of ethno-cultural understandings of national belonging, in some instances became the qualifying criterion for mobile EU citizens' legitimate inclusion in welfare receipt. The findings allow conclusions to be drawn on how ideas about national belonging may impact street-level bureaucrats' perceptions of deservingness. Following a cultural performance-based logic, street-level bureaucrats tended to see mobile EU citizens as deserving of tax-financed state social support once they behaved like German-born nationals, being acquainted with the language and the dominant socio-cultural norms.

Considering local administrators' roles as gatekeepers of public benefits and services, as described in the street-level bureaucracy literature, their interpretations of mobile EU citizens' social legitimacy in claiming can bring about important distributional consequences. Imposing hidden administrative costs beyond what the law requires, street-level bureaucrats may prevent those mobile EU citizens whom they consider undeserving from securing subsistence in Germany.

\section{Concluding thoughts on the figure of the deserving EU migrant claimant}

This article has discussed the ways in which street-level bureaucrats ration mobile EU citizens' access to social assistance-type benefits in Germany, and the rationales they mobilise to justify exclusionary practices. The findings contribute to new understandings about ideas of deservingness when it comes to extending welfare entitlements to noncitizens. In summary, local job centre administrators predominantly saw mobile EU citizens as foreigners, and therefore as less deserving of tax-financed social subsistence benefits in Germany than their fellow German-born applicants. Nationalistic or ethnicising readings of (not) being 'German enough', relating to van Oorschot's (2008) identity-based criterion of deservingness, informed street-level bureaucrats' views on the legitimacy of mobile EU citizens' entitlements to social assistance in Germany. Either EU migrant claimants were considered illegitimate bearers of social rights in Germany due to their outsider status and were expected to be self-sufficient, following an economic-performance logic; or frontline staff made access to social benefits conditional upon performing national belonging by demonstrating acquiescence with the German language and societal norms, as a form of cultural performance-based logic of deservingness.

In more detail, some street-level bureaucrats portrayed EU migrant claimants as transnational journeyers who sought to illegitimately access limited public resources and 
called for their exclusion from substantive benefit receipt. Front-line staff often considered Eastern European claimants particularly undeserving, based on stereotyped representations of endemic welfare abuse as a representative attribute of anyone sharing the same nationality. Their discursive framing closely mapped onto institutionalised ideas of social tourism featuring in German public and policy discourse. The latter emphasised the important requirement 'to work and contribute' first to gain legitimate social entitlements in Germany and identified mobile EU citizens from Central and Eastern European as particularly prone to social tourism (see Ratzmann, 2019: 184-189). The interview data substantiate Dwyer et al.'s (2019: 138) idea of 'institutionalised welfare chauvinism', whereby street-level perceptions of EU citizens' deservingness to claim social support are never independent of the larger policy rhetoric. As Lipsky (2010: 109) noted, 'there is every reason to think that the general evaluations of social worth that inform the society will also inform the decisions of street-level bureaucrats'.

Other street-level bureaucrats set out qualifying cultural conditions whereby deservingness could be earned through performing national belonging. Some local administrators were willing to grant access to welfare benefits as a reward for cultural assimilation efforts. Failure to comply with, or to perform in response to, such implicitly set out integration demands led front-line staff to judge intra-EU claimants as non-belonging and hence undeserving of membership in the redistributive community of welfare. Like the nationalistic turn of civic integration programmes in other European countries (see Farris, 2017), exclusionary policies on accessing social assistance in Germany became justified through attitude or behaviour. Street-level bureaucrats portrayed knowledge of the German language as a central element of such socio-cultural adaptation processes, which can be related to Germany's nation-building experience. The imaginary community of the German nation was built upon the collective myth of an entity 'where people speak German' (Hogwood, 2000), foregrounding ethno-cultural criteria of membership.

Overall, the findings illustrate how EU social citizenship loses part of its meaning at local level. EU citizens can face similar barriers to those faced by other foreign claimants when seeking access to social benefits and services in an unfamiliar domestic context. Dynamics of local policy implementation stratify EU social citizenship rights beyond legal entitlements and employment activation-related conditionalities, influenced by ideas about identity and deservingness. Those who become socially constructed and 'othered' as 'foreigners' are commonly not seen as part of the community of solidarity. In consequence, European social citizenship remains linked to ideas of nationhood and nationally-bound solidarities.

\section{Acknowledgements}

I am indebted to the interviewees who made this research possible, and I would like to extend special thanks to Hartley Dean, Isabel Shutes and Peter Dwyer for their valuable comments on earlier drafts of this work. Finally, my thanks go to the Leverhulme Trust UK, whose funding made this research possible.

\section{References}

Anderson, B. (2015) 'Immigration and the worker citizen', in B. Anderson and V. Hughes (eds.), Citizenship and its Others, Basingstoke: Palgrave Macmillan, 41-57. 
Bacchi, C. L. (2009) Analysing Policy: What's the Problem Represented to Be? Frenchs Forest, N.S.W.: Pearson Australia.

Bonjour, S. and Duyvendak, J. W. (2018) 'The "migrant with poor prospects": racialized intersections of class and culture in Dutch civic integration debates', Ethnic and Racial Studies, 41, 5, 882-900.

Breidahl, K. N. (2012) 'Immigrant-targeted activation policies: a comparison of the approaches in the Scandinavian welfare states', in M. Kilkey, G. Ramia and K. Farnsworth (eds.), Social Policy Review 24. Analysis and Debate in Social Policy, Bristol: Policy Press, 117-36.

Brodkin, E. Z. (2013) 'Street-level organisations and the welfare state', in E. Z. Brodkin and G. Marston (eds.), Work and the Welfare State. Street-Level Organizations and Workfare Politics, Washington D.C.: Georgetown University Press, 17-34.

Bundesamt für Migration und Flüchtlinge (2018) 2016/2017 Migration Report: Key Results, Bundesamt für Migration und Flüchtlinge, Nürnberg.

Chauvin, S., Garcés-Mascareñas, B. and Kraler, A. (2013) 'Employment and migrant deservingness', International Migration, 51, 6, 80-85.

Dubois, V. (1996) 'Une institution redéfinie par ses usage(r)s? [Sur quelques pratiques du guichet dans les CAF]', Recherches et Prévisions, 45, 1, 5-13.

Dwyer, P. J., Scullion, L., Jones, K. and Stewart, A. (2019) 'The impact of conditionality on the welfare rights of EU migrants in the UK', Policy and Politics, 47, 1, 133-50.

Farris, S. R. (2017) In the Name of Women's Rights: The Rise of Femonationalism, Durham: Duke University Press.

Heuer, J-O. and Mau, S. (2015) 'Stretching the limits of solidarity: the German case', 03-05.09.2015, ESPAnet, Odense, Denmark.

Hogwood, P. (2000) 'Citizenship controversies in Germany: the twin legacy of Völkisch nationalism and the Alleinvertretungsanspruch', German Politics, 9, 3, 125-44.

Jewell, C. J. (2007) Agents of the Welfare State: How Caseworkers Respond to Need in the United States, Germany and Sweden, New York: Palgrave Macmillan.

Lipsky, M. (2010) Street-Level Bureaucracy: Dilemmas of the Individual in Public Service, 30th Anniversary Expanded Edition, New York: Russell Sage Foundation.

Lockwood, D. (1996) 'Civic integration and class formation', The British Journal of Sociology, 47, 3, 531-50.

Maynard-Moody, S. and Musheno, M. (2000) 'State agent or citizen agent: two narratives of discretion', Journal of Public Administration Research and Theory, 10, 2, 329-58.

Maynard-Moody, S. and Musheno, M. (2012) 'Social equities and inequities in practice: street-level workers as agents and pragmatists', Public Administration Review, 72, S1, S16-S23.

Miles, M. and Huberman, M. (1994) Qualitative Data Analysis: An Expanded Sourcebook, Thousand Oaks: Sage Publications.

Miles, R. and Brown, M. (2003) Racism, 2nd edn, London: Routledge.

Mourão Permoser, J. (2017) 'Redefining membership: restrictive rights and categorisation in European Union migration policy', Journal of Ethnic and Migration Studies, 43, 15, 2536-55.

Ratzmann, N. (2019) Caught between the Local and the (Trans)National EU Citizens at the Front-line of German Welfare Policy, PhD thesis, The London School of Economics and Political Science (LSE).

Reeskens, T. and van der Meer, T. (2015) 'The color of benefits: a large-scale survey experiment on the importance of ethnicity as deservingness heuristic', 25 February, MaDColloquium, WZB Berlin Social Science Center.

Shutes, I. and Walker, S. (2017) 'Gender and free movement: EU migrant women's access to residence and social rights in the UK', Journal of Ethnic and Migration Studies, 44, 1, 137-53.

Soysal, Y. N. (1994) Limits of Citizenship: Migrants and Postnational Membership in Europe, Chicago, London: University of Chicago Press.

Statistisches Bundesamt (Destatis) (2017) Bevölkerung und Erwerbstätigkeit: Ausländische Bevölkerung, Ergebnisse des Ausländerzentralregisters - Fachserie 1 Reihe 2-2017, Statistisches Bundesamt: Wiesbaden.

Tesch, R. (1990) Qualitative Research: Analysis Types and Software Tools, New York: Falmer Press. 
van Oorschot, W. (2006) 'Making the difference in social Europe: deservingness perceptions among citizens of European welfare states', Journal of European Social Policy, 16, 1, 23-42.

van Oorschot, W. (2008) 'Solidarity towards immigrants in European welfare states', International Journal of Social Welfare, 17, 1, 3-14.

Wright, S. (2003) Confronting Unemployment in a Street-Level Bureaucracy: Jobcentre Staff and Client Perspectives, Thesis submitted for the degree of Doctor of Philosophy, University of Stirling.

Zacka, B. (2017) When the State Meets the Street: Public Service and Moral Agency, Cambridge, MA: Harvard University Press (Belknap Press).

Zimmermann, K. and Rice, D. (2016) 'Organizational barriers to service integration in one-stop shops: the case of Germany', in M. Heidenreich and D. Rice (eds.), Integrating Social and Employment Policies in Europe: Active Inclusion and Challenges for Local Welfare Governance, Cheltenham: Edward Elgar Publishing, 162-84. 